\title{
Migrants in the Attic: The Case of Migrants with Disabilities and Resettlement Services in Serbia
}

\author{
Joel John Badali
}

check for updates

Citation: Badali, Joel John. 2021. Migrants in the Attic: The Case of Migrants with Disabilities and Resettlement Services in Serbia. Laws 10: 10. https://doi.org/10.3390/ laws10010010

Received: 2 November 2020

Accepted: 4 February 2021

Published: 10 February 2021

Publisher's Note: MDPI stays neutral with regard to jurisdictional claims in published maps and institutional affiliations.

Copyright: (C) 2021 by the author. Licensee MDPI, Basel, Switzerland. This article is an open access article distributed under the terms and conditions of the Creative Commons Attribution (CC BY) license (https:/ / creativecommons.org/licenses/by/ $4.0 /)$.
Independent Researcher, Iqaluit, Nunavut, NU X0A 0H0, Canada; joel.badali@gmail.com

\begin{abstract}
The global migrant crisis triggered an unprecedented number of asylum seekers in the Balkan region. In this case study, the state of migrants with disabilities-a community notoriously overlooked during global conflict-is explored through field interviews of settlement service providers in Serbia. A human rights framework is espoused in first examining contemporary refugee law discourse and the corresponding gaps in current resettlement practice of migrants with disabilities. The study's findings illuminate the need for a drastic shift in settlement services for those migrants most vulnerable to persecution in de facto destination countries. The discussion takes aim at "humanitarian silo" funding models and argues for international cooperation and transparency in accommodating migrants with disabilities internationally.
\end{abstract}

Keywords: migrants; disability; migrant crisis; disability rights; human rights; refugee; Serbia

\section{Overview}

Globally, the number of displaced peoples reached an all-time high this past decade, eclipsing the refugee crisis precipitated by the Second World War (UNHCR 2017a, pp. 5, 44; UNHCR 2020). During the European migrant crisis, over a million migrants passed through Serbia en route to Western Europe (EC 2017). With the closure of the Balkan route, Serbia-a former transit country, was home to over seven thousand migrants in 2017, many of whom resided there for well over a year (UNHCR 2017b). As the number of arriving migrants crests (UNHCR 2017a, pp. 39-40), the plight of migrants amid stagnating asylum claims is mirrored by the challenges facing settlement services and non-governmental organizations (NGOs), exposing human rights violations toward migrants with disabilities in Serbia (Morris and Souhmahoro 2017, p. 319).

The current case study argues for settlement models adapted to the needs of migrants with disabilities in times of humanitarian crisis. The status of this community is analyzed in view of Serbia's unique socio-political dynamics, while locating migrants' rights in the broader human rights and legal rhetoric of continental Europe. In the Introduction, the exploration of migrants with disabilities is first situated in contemporary disability rights discourse. Second, the state of the current migrant crisis is presented relative to the Balkan region, Central Europe, and Turkey. Serbia's socio-political climate is then discussed with respect to both migrants' and people with disabilities' rights. Finally, the relevance of international and European human rights instruments and case law is discussed in reference to Serbia's formalized candidacy for the European Union [EU]. Finally, the research question guiding this case study is presented.

In the Methods section, the process of conducting field interviews with key informants is discussed toward the objective of better understanding the de facto status of migrants with disabilities. The methodological and analytical framework guiding the interviews is presented, and is followed by the Key Findings section which presents three key themes that emerged from these data. Finally, the Discussion reconsiders the human rights of migrants with disabilities in light of these interviews, providing lessons learned from the migrant crisis in Serbia and recommendations to better protect the rights of migrants with disabilities internationally. 


\section{Introduction}

\subsection{Contemporary Disability Rights Discourse}

The dignity of peoples with disability has been historically undervalued in the realm of human rights discourse the globe over (Basser 2001). This article therefore understands the emergence of disability rights internationally as a relatively recent social phenomenon (Mackelprang and Salsgiver 2016). Having been previously understood through charitable and medical models (Harpur 2012), it was not until 2008 that the Convention on the Rights of Persons with Disabilities [CRPD] concretized a human rights approach to disability. The CRPD characterized disability in terms of the impairment resulting from societal barriers, and not the disability itself. Within the context of human conflicts and disaster, migrants with disabilities have been furthermore overlooked, a trend that is slowly changing (Crock et al. 2017).

The European Parliament's 2016 Report on the Implementation of the CRPD situates the CRPD as a tool to promote a human-rights-based approach to disability. This approach stresses the importance of human rights for people with disabilities in situations of humanitarian crises and socio-political conflict (EC 2016a). The report also calls for the mainstreaming of disability rights in migration and refugee policies, "recognis[ing] that vulnerable members of society are further marginalised if they have a disability, and stresses that the EU institutions and the Member States should redouble their efforts to accommodate fully the provision of rights and services for all persons with disabilities, including [...] refugees and asylum seekers" (EC 2016a).

Disability for the purpose of this article is defined through the lens of the CRPD, by recognizing that "disability is an evolving concept and that disability results from the interaction between persons with impairments and attitudinal and environmental barriers that hinders their full and effective participation in society on an equal basis with others" (UN 2008). In addition, "Persons with disabilities include those who have long-term physical, mental, intellectual or sensory impairments which in interaction with various barriers may hinder their full and effective participation in society on an equal basis with others" (CRPD, Article 1). This case study therefore orients itself using a social and human rights approach to disability, locating 'disability' broadly as the product of environmental, structural, and societal deficits, and not solely as medical barriers facing migrants.

\subsection{The Migrant Crisis in the Balkan Region}

Serbia finds itself amid growing political conservatism in the resettlement of asylumseekers. ${ }^{1}$ As of early 2016, under the "EU-Turkey deal", migrants have been effectively prevented from penetrating the EU via Turkey. ${ }^{2}$ The deal provided that migrants in Greece arriving from Turkey who are not applying for asylum in Greece or who are found to be inadmissible according to agencies under the directives of the UNHCR are to be returned to Turkey. In the aftermath of the EU-Turkey deal, rampant mental health issues were reported among migrants including depression, PTSD, and suicidality (Squire 2017). Human rights organizations decried the EU-Turkey deal on account of the violations of human rights and refugee protections enshrined in the Geneva Convention 1951 (Gogou 2017).

In the same year, similar rhetoric around migrant resettlement emerged in Central Europe and the Balkans. The shift to anti-migrant policies ${ }^{3}$ precipitated equally restrictive measures on migrants in countries with borders contiguous to Serbia. Within the EU,

1 Asylum-seekers and refugees, although distinct legal terms, are often conflated. Asylum-seekers generally are applying for State protection whether through international law or local protection mechanisms from within that State. Refugees are already granted a State's protection, having generally applied from outside that country or successfully made an asylum claim within the host country. Migrants passing through Serbia to reach a safe country would, by definition, be considered asylum-seekers and not refugees. Regardless, the same legal standards with respect to persecution apply under the Geneva Convention. For the purposes of this article 'migrants' refers broadly to refugees and asylum-seekers in Serbia.

2 With respect to specifically Syrian migrants, for each Syrian returned to Turkey, another Syrian shall be granted asylum in an EU country. See Council of the EU, Press Release, 144/16, "EU-Turkey Statement, 18 March 2016" (18 March 2016), European Council Press Releases. Available online: http:/ /www.consilium.europa.eu/en/press/press-releases/2016/03/18/eu-turkey-statement/ (accessed on 14 January 2021).

3 See for examples (Beznec et al. 2016, pp. 55-60). 
Hungary built successive fences along its borders with Serbia whereas Bulgaria and Croatia used other measures to stem the flow of migrants travelling through Serbia. ${ }^{4}$ These barriers left many migrants in border towns in Northern Serbia in precarious living conditions, and the length of their duration increasingly uncertain (Aljazeera 2016).

In the aftermath of the closure of the Balkan route, thousands of migrants were effectively stranded in Serbia (Speer 2017). The number of asylum-seekers, the majority of whom reside in government shelters peaked in mid-2017 at nearly 8000, however nearly 5000 remain, with hundreds of new arrivals on a monthly basis from Bulgaria and the Former Yugoslave Republic of Macedonia (now Republic of North Macedonia) (UNHCR 2017c). The politics of the migrant crisis reveal not only the pattern of long-term settlement of asylum seekers through which transit countries emerge as de facto destination countries, but also the consequence of these dynamics on the endemic denial of migrants with disabilities' human rights.

\subsection{Disability Rights in Serbia: Under the EU Spotlight}

In recent years, Serbia has been lauded for its migrant resettlement initiatives. ${ }^{5}$ Serbia's international reputation however, is marred by decades of human rights abuses among marginalized communities (Human Rights Watch 2017). People with disabilities in particular are on the margins of Serbian society. People with disabilities experience structural discrimination through segregation in the public education system (EC 2016b, p. 63), lack of employment opportunities (51), and lack of access to justice (64). The institutionalization of people with disabilities however, poses the most extensive human rights violations of peoples with disabilities in Serbia (61).

Serbians who are institutionalized are overwhelmingly deprived of their legal capacity (EC 2016b, p. 63), isolating them physically and socially from mainstream society. This process oftentimes leaves people with intellectual and psychiatric disorders institutionalized for the duration of their life, and discourages the public from openly discussing mental health (MDRI-S 2011). Institutionalized Serbians are exposed to gender-based violence and many women have been forcibly sterilized (UN Committee on the Rights of Persons with Disabilities). Civil society organizations monitoring these institutions find the conditions not only violate the CPRD but constitute systematic torture under the UN Convention Against Torture and Other Cruel, Inhuman or Degrading Treatment or Punishment [CAT] (MDRI-S 2011). As a candidate for EU membership, Serbia's accession hinges in part on improving its human rights record for people with disabilities.

Serbia's integration into the EU requires leveraging policies of both the EU and UN. The EU was established foremost to guarantee freedom, security and justice among its member states (Treaty on the Functioning of the European Union 2007). Acceding countries must accordingly demonstrate minimum standards in the preservation of democratic governance and the rule of law, including "a respect for and protection of minorities" 6 A 2016 European Commission report on Serbia's accession finds that the legal mechanisms

4 As well, push back has similarly been reported in other Central European States. See (Voynov et al. 2017).

5 See for example RadioFreeEurope, News Release, “Merkel Praises Serbia's Handling of Migrants Taking Balkan Route to EU” (15 March 2017). Available online: https:/ / www.rferl.org/a/german-chancellor-merkel-praises-serbia-handling-migrant-crisis-balkan-route-eu/28370171.html. See also Andrew Macdowall, "Wait, the Serbs are Now the Good Guys?", (18 September 2015). Politico. Available online: https:/ /www.politico.eu/ article/serbia-croatia-hungary-orban-migrants-schengen-crisis/ (accessed on 14 January 2021).

6 As per the "Copenhagen Criteria" of the European Union, acceding countries from Central and Eastern Europe must meet minimum requirements which include Membership requires that the candidate country has achieved stability of institutions guaranteeing democracy, the rule of law, human rights and respect for and protection of minorities, the existence of a functioning market economy as well as the capacity to cope with competitive pressure and market forces within the Union. (EC, Presidency Conclusions Cophenhagen European Council, [1993], at 1.) 
to protect the rights of peoples with disabilities is established, but in practice these rights have not been guaranteed (EC 2016b, p. 19). ${ }^{7}$

The EU also seeks to have Member States implement the United Nations Sustainable Development Goals [SDGs] (EC 2016c). In accordance with the EU accession process, Serbia maintains certain prioritized SDG goals, revealing intersections between accession goals and disability rights (UNDP 2017). These prioritized SDGs call for the eradication of poverty and a rights-based approach to development, recognizing the multifarious factors undergirding discrimination such as unequal protection of rights and the need for multi-dimensional programs and policies (EC 2016d, p. 5).

Serbia's prioritized SDGs also call for a more "comprehensive" approach to the migrant crisis that asserts the respect of migrants' fundamental rights and mutual accountability between States (EC 2016d, p. 12). In addition, Goal 16 Peace, Justice and Strong Institutions is among the main actions contributing to the EU's strategy on integration of the SDGs (EC 2016d, p. 6). The UN states that this goal "is dedicated to the promotion of [...] inclusive societies for sustainable development [and] the provision of access to justice for all [...]" (EC 2016e, p. 127). Yet, the UNHCR does not collect statistics on migrants with disabilities (Crock et al. 2017). The prospect of EU inclusion therefore heightens the necessity for human rights protections and monitoring of peoples with disabilities in Serbia.

In the context of the enduring migrant crisis, upholding the rights of migrants with disabilities is further critical to meeting the goals set out by EU and SDGs. The following section outlines how human rights protections for migrants with disabilities apply to migrants in Serbia through both international human rights conventions and European law.

\subsection{Socio-Legal Context of Migrants with Disabilities in Serbia: Migrant Rights in Theory}

Historically, migrants with disabilities have been disadvantaged in the asylum and refugee claimant process. However, recent legal protections and human rights instruments dictate additional protections for migrants with disabilities in Europe. This section details the relevant legal and human rights standards applicable to Serbia in meeting the aforementioned preconditions necessary for EU accession.

First, migrants' legal entitlements to equality and non-discrimination are enshrined in international and European conventions. The International Covenant on Civil and Political Rights provides that all individuals within a nation's territory be subject to equality and non-discrimination before the law (UN 1966, Articles 2(1) \& 26). The European Convention on Human Rights, ratified by Serbia in 2004, also specifies the non-discrimination in an individual's enjoyment of their legal rights on the basis of grounds including sex, race, political opinion, and "other status[es]" (ECHR 1950). The European Union Charter of Fundamental Rights (Charter) further qualifies additional grounds for non-discrimination in legal rights, specifying discrimination on the basis of "disability" in addition to providing for the integration of persons with disabilities (Charter of Fundamental Rights of the European Union 2000). Under this Charter, rights to equality-including for people with disabilities within EU member states—further applies regardless of nationality (Peers et al. 2015). Al-

\footnotetext{
The rights of peoples with disabilities in Serbia are protected in its constitution. The Constitution of the Republic of Serbia guarantees human and minority rights with specific reference to international standards. Article 18 states, "Provisions on human and minority rights shall be interpreted to the benefit of promoting values of a democratic society, pursuant to valid international standards in human and minority rights, as well as the practice of international institutions which supervise their implementation." Article 21 "prevents discrimination on several enumerated grounds including mental or physical disability. Measures taken to protect and better serve substantially disadvantaged groups does not constitute discrimination." Human dignity and the inviobility of people with disabilities are enshrined in Articles 23 and 25, respectively, and derogations of the therefrom are not permitted. See Constitution of the Republic of Serbia, Republic of Serbia, 2006, Official Gazette of the RS 98/06 (Republic of Serbia). A general framework for anti-discrimination against people with disabilities is set up by the Law for Prevention of Discrimination against Persons with Disabilities. See Law on the Prevention of Discrimination against Persons with Disabilities, Republic of Serbia, 2006, Official Gazette of the RS 33/06. See also Republic of Serbia, Anti-Discrimination Strategy for 2013-2018, 5 October 2011, Official Gazette of the RS $1089 / 11$ (Republic of Serbia). The protection of Serbia's Constitutional rights however has been criticized under EU accession screening reports. See EC, Screening Report Serbia: Chapter 23 Judiciary and Fundamental Rights, [15 May 2014], MD 45/14 at 14.
} 
though not bound by the Charter yet, given Serbia's tentative accession, this instrument nonetheless raises the stakes for the domestic protection of migrants with disabilities.

A 2011 directive by the EU solidifies the rights of people with disabilities in the purview of international protection (EC 2011). Articles 20.3 and 30.2 provide for the protection of rights of migrants who are physically disabled or present with mental disorders.

Member States shall provide, under the same eligibility conditions as nationals of the Member State that has granted protection, adequate healthcare, including treatment of mental disorders when needed, to beneficiaries of international protection who have special needs, such as [...] disabled people, [and people who have experienced psychological, physical or sexual violence]. (EC 2011, Article 30.2)

Disability also factors into EU States' asylum processes for migrants. Applying the Charter, courts consider gender, age, and disability in assessing the extent to which a migrant is exposed to persecution (Peers et al. 2015).

On the other hand, the European Court of Human Rights' (ECtHR) rulings do apply to Serbia. ECtHR jurisprudence applies to all Council of Europe [CoE] States, to which Serbia is a signatory as of 2003 (Committee of Ministers of the Council of Europe 2006). This court has extended "implied" legal protection on the grounds of "other status" to people with disabilities through the court's jurisprudence (Ktistakis 2016). Therefore, though not part of the EU, additional European laws protect the rights of migrants with disabilities in Serbia.

The ECtHR also oversees the implementation of the European Convention on Human Rights (ECHR), which provides for appropriate accommodations of migrants in Europe. For example, Article 3 of the Convention states "No one shall be subjected to torture or to inhuman or degrading treatment or punishment" (ECHR 1950, Article 3). The ECtHR has interpreted this article broadly, affirming its "absolute character", thereby necessitating conditions in detention centres that uphold human dignity in addition to the provision of medical needs in all member states (Ktistakis 2016, pp. 36-37). In M.S.S. v Belgium and Greece (2011) the Court provides that CoE members cannot derogate from their obligations, despite the disproportionate arrivals of migrants relative to States' capacities and regardless of economic or social circumstances (ECtHR 2011, pp. 45-46). ${ }^{8}$

The CoE itself has articulated on many occasions that migrants are not to be treated like prisoners, particularly given that they already experience a loss of liberty having been forced to leave their country of origin (Ktistakis 2016, p. 34). The facilities housing migrants must accordingly not deprive their liberty, and additionally be "suited for their specific situation" (Ktistakis 2016, p. 34). In contemplating protracted asylum process claims, the Committee of Ministers, the body responsible for overseeing ECtHR rulings (ECHR 1950, Article 46), calls for "facilities specifically designed for that purpose, offering material conditions and a regime appropriate to their [migrants'] legal and factual situation by suitably qualified personnel" (Committee of Ministers of the Council of Europe 2019).

The CoE Commissioner for Human Rights further affirms that:

"[a]rriving migrants (including irregular migrants and asylum-seekers) shall be treated with full respect for their human dignity. They shall be provided with necessary social and medical assistance, including emergency treatment. Accommodation facilities (e.g., reception or detention centres), food and living conditions provided to migrants must meet basic standards of decency" . (Council of Europe 2011, Article II(a)(3))

In MSS v Belgium and Greece (21 January 2011 para. 223), the ECtHR applies Article 3 to further entrench the rights to adequate standards of living for migrants in view of the increasing regional migrant claims, regardless of whether migrants reside in government reception centres or detention centres, "The Court notes first of all that the States which form the external borders of the European Union are currently experiencing considerable difficulties in coping with the increasing influx of migrants and asylum seekers. [ ... The court] is particularly aware of the difficulties involved in the reception of migrants and asylum seekers [and the disproportionate burden] when compared to some of these States. [...] The absolute character of Article 3 cannot absolve a State of its obligations under that provision". 
In Musial v Poland, the ECtHR provides for "increased vigilance" in applying the ECHR, calling for appropriate services for migrants with physical and mental disabilities (ECtHR 2009). These provisions include the provision of therapeutic services to preserve both migrants' mental and physical health (ECtHR 2009, pp. 29-30). Failure to provide appropriate treatment for mental illnesses or physical disabilities violates migrants' human rights contrary to States' obligations under Article 3 (Ktistakis 2016, p. 41).

These CoE guidelines and ECtHR jurisprudence ground the heightened standards of accommodation for migrants in Serbia, standards which may prove furthermore challenging in accommodating migrants with disabilities. Serbia's accession to the EU resides in upholding the rule of law, underscoring the urgency of human rights protections for migrants with disabilities.

Finally, the Convention for the Rights of Persons with Disabilities (CRPD), signed by Serbia in 2007, also applies to migrants (UN 2008). Article 18, for example, guarantees the liberty of movement of peoples with disabilities on an equal basis as others, including access to "relevant processes, such as immigration proceedings, that may be needed to facilitate exercise of the right to liberty of movement" (Article 18(1)(b)). The CoE's manual for legal practitioners reaffirms that migrants in Europe also enjoy the rights set out in the CRPD (Ktistakis 2016, p. 15).

Scholars in the field have previously explored the ways in which human rights instruments such as the CRPD can theoretically inform the rights of migrants with disabilities. Hathaway (1991) for example, suggests that the extent to which refugee law protections can be invoked is contingent on the human rights that are not being protected by a State itself. Human rights instruments ought to thus be read in tandem with refugee protection law in order to inform the extent to which an individual merits protection (Hathaway 1991, p. 120). In the realm of human rights law, particularly with respect to the CRPD's evolving definition of disability (UN 2008), its application insofar as migrants with disabilities is nebulous (Peterson 2014, p. 690).

Peterson uses the evolving conception of disability outlined in the CRPD to argue for expanded rights of asylum seekers and refugees with disabilities. The CRPD ought to inform the rights of migrants with disabilities in two ways. First, the CRPD buttresses the classical frameworks for adjudicating refugee and asylum claims, for example, by fitting claimants within the Geneva Convention definition of a refugee, meaning someone "belonging to a particular social group" (Peterson 2014, p. 695).

On the other hand, the CRPD can be applied "defensively", by demonstrating that treatment toward an individual with a disability is in violation of the CRPD to the degree that the treatment constitutes itself persecution or torture under the CAT (Peterson 2014, p. 690). The latter usage fits within the ECtHR's consistent approach in applying Article $3^{9}$ as a defence for migrants facing inhumane conditions in States' accommodation centres (Ktistakis 2016, pp. 34-35). The CRPD, in effect, ought to be read in conjunction with States' refugee and asylum protection laws in order to ensure that the CRPD protects claimants where State law fails (Peterson 2014).

The CRPD also provides under Article 11, for "all necessary measures" to be taken to protect people with disabilities in situations of conflict and humanitarian emergencies (UN 2008). This article was explicitly applied with reference to the migrant crisis under a 2016 Report on the implementation of the UN Convention on the Rights of Persons with Disabilities (EC 2016a, para. 59). With reference to "resolving the refugee issue", the European Parliament calls for the European Commission and Euro Council States "when making proposals for resolving the refugee issue, for funding or for other support measures, to provide for special care for persons with disabilities". In its August 2016 "Thematic Focus:

9 "3(1) No State Party shall expel, return ("refouler") or extradite a person to another State where there are substantial grounds for believing that he would be in danger of being subjected to torture. (2) For the purpose of determining whether there are such grounds, the competent authorities shall take into account all relevant considerations including, where applicable, the existence in the State concerned of a consistent pattern of gross, flagrant or mass violations of human rights." See Convention Against Torture and Other Cruel, Inhuman or Degrading Treatment or Punishment (CAT), 26 June 1987, UNTS 1465 (entered into force 26 June 1987, succeeded by Serbia 24 March 2001). 
Migrants with Disabilities", the European Union Agency for Fundamental Rights also noted that the CRPD Committee remained "deep[ly] concern[ed] with the precarious situation of persons with disabilities in the current migration crisis in the EU" by highlighting the lack of reasonable accommodations for migrants with disabilities and general lack of accessibility. ${ }^{10}$

Based on existing refugee law and the CRPD, migrants with disabilities in Serbia are legally entitled to additional, specific protections. European jurisprudence and international human rights conventions illustrate that violations of people with disabilities is a legitimate basis for claiming asylum. Moreover, this community's rights are justifiably protected throughout migrants' protracted asylum and refugee claims in Europe. Crucially, in view of Serbia's human rights record, international legal obligations, and EU accession imperatives, the protection of migrants with disabilities sheds light on the impending legal standards required of Serbia in migrant accommodations.

\subsection{Research Question}

This case study explores how Serbian human rights organizations and settlement services are addressing the human rights and corresponding entitlements of migrants with disabilities. Research on the reality of migrants with disabilities' enjoyment of human rights is sparse (Crock et al. 2017). Disability among migrants remains chronically underreported while existing registration mechanisms do not adequately "capture the full range of physical and mental disabilities" among this population (Crock et al. 2017, p. 4). Yet migrants fleeing social conflict, for example from Syria, are disproportionately burdened by disability (Handicap International 2014). Moreover, little is known about the accommodations made for migrants with disabilities (Crock et al. 2017), while dedicated funding for this community is implored by various United Nations committees ${ }^{11}$ and the European Parliament (EC 2017, para. 141). The dearth of research addressing migrants with disabilities, and in particular addressing this community's rights as human rights, illuminates the need for research that addresses how settlement services uphold this community's rights. The key informants bring this issue into focus by informing the guiding research question: How do service providers in Serbia understand, and accommodate, the rights of migrants with disabilities in practice?

\section{Methods}

\subsection{Case Study Methodology}

Given the crossroads at which disability rights are located in Serbia, a case study is adopted to examine the nuances of Serbia's accommodation of migrants with disabilities. First, a case study grounds itself in a social constructionist worldview. The behavior of individuals is viewed as interlocking with social and environmental influences and thus social constructionist research seeks to understand qualitatively how and why certain relations exist (Gagnon 2010, pp. 13-14). Social constructionism applies to a case study for the very reason that multiple viewpoints inform this reality, or the social phenomenon, at hand.

Accordingly, a case study methodology encourages canvassing a variety of sources. Case studies are also used in setting wherein organizations are canvassed. Gagnon implores the importance of exploring organizational settings in a case study specifically because "we must understand how things happen before considering why." (Gagnon 2010, pp. 13-14)

10 They also note the EU "Asylum Procedures Directive requiring that asylees with disabilities and mental disorders, may be in need of special guarantees and [...] should be provided with adequate support". See European Union Agency for Fundamental Rights, "Thematic Focus: "Migrants with Disabilities", (August 2016), Regular Overviews. Available online: https:/ / fra.europa.eu/sites/default/files/fra_uploads / fra-august-2016 -monthly-migration-disability-focus_en.pdf (accessed on 17 February 2021).

11 See joint statement by Committee on Migrant Workers and Committee on the Rights of Persons with Disabilities: United Nations Human Rights Office of the High Commissioner, "Migrants and Refugees with Disabilities Must Be Priority in New Global Compact on Migration-UN Experts." United Nations Human Rights Office of the High Commissioner News and Events. Available online: http:/ /www.ohchr.org/EN/NewsEvents/Pages/ DisplayNews.aspx?NewsID=21495\&LangID=E (accessed on 14 January 2021). 
A case study is therefore effective in examining contemporary events wherein a solid theoretical base for research does not otherwise exist (Gagnon 2010, pp. 16-17).

With regard to data collection, interpersonal relationships are also stressed in conducting a case study. For example, relationships of trust must be established with individuals in the setting observed. Gagnon (2010, pp. 58-59) points to the necessity for a researcher to have been immersed in the environment they explore and practice active listening. The primary investigator leveraged their past work conducting research with refugees and managing programs for them in order to build harmonious relationships with the organizations solicited in this study. Furthermore, this researcher spent three months working within a civil society organization in Serbia, completing research on human rights-related issues in situ. It follows then that a snowball sample was used to obtain participants from local service providers and use these initial interviewees to recruit additional participants who they thought might be instructive to the case. Snowball sampling has furthermore been advised in the context of research with a specific recruitment base and on potentially controversial issues (Warren 2002). Although not all participants were involved directly in human rights advocacy for migrants with disabilities, the diversity of sources nonetheless broadens the organizational and social context in which CSOs and NGOs operate in Serbia.

Case studies also employ semi-structured interviews. In the current study, a semistructured interview was employed to allow the interviewer to focus in on topical issues facing migrants with disabilities but also allow leeway for participants to address issues organically (Gagnon 2010, p. 61).

The relational aspect stressed by case study methodology also came through in conducting a 'member-check' with participants. Member-checking is the process of returning transcripts or information provided by participants in qualitative research to ensure its accuracy, thereby contributing the internal validity of the research (Birt et al. 2016). In this study, all participants were followed up by email, four of whom provided corrections and clarifications to quotations used in the findings.

\subsection{Key Informant Interviews}

Given the aforementioned paucity of knowledge on migrants with disabilities, and the relative urgency of their need in Serbia, interviews were conducted with 'key informants' 12 . The recruitment of key informants was carried out using a snowball process, wherein contacts from this researcher's professional networks were used to recommend organizations who fit the desired informational profile (Warren 2002). Interview questions were open-ended. They inquired about the visibility of migrants with disabilities and service providers' awareness of those needs, and how services were adapting to emerging needs of long-term migrants, in particular those with disabilities. For example, a question asked was, "How are your organization's services adapting to the changing needs of migrants?" Ten interviews were conducted, all in English, each lasting between one half hour to one hour. Limitations are discussed in the section entitled "Moving Forward and Recommendations".

Eleven participants initially obliged; however, an interview with the Public Relations Officer of the Commissariat for Refugees and Migration Recruitment was not pursued further after repeated unreplied emails and phone messages (despite a brief conversation by phone to schedule a date). Recruitment ended when the organizations suggested by participants had been exhausted. Interviews were recorded with the consent of people being interviewed after seeking ethical clearance from MDRI-S to conduct interviews on the organization's behalf. All interviews were conducted in August and September 2017. Interviewers were between their mid-20s and mid-50s, and evenly divided between

12 Key informants included representatives from international agencies and local settlement service providers in Serbia, from on-the-ground support (Medecins Sans Frontieres [http://www.msf.org/en/where-we-work/serbia], Red Cross of Serbia [https://www.redcross.org.rs/], International Aid Network [http://www.ian.org.rs/]), to longer term support and settlement services (Info Park [no website], Psychosocial Innovation Network [psychosocialinnovation.net/en/]), policy analysts and human rights monitoring organizations (UNHCR Serbia [http: //www.unhcr.org/serbia.html], Belgrade Centre for Human Rights [http://www.bgcentar.org.rs/bgcentar/eng-lat/]), and legal advocates (Praxis [https://www.praxis.org.rs/], YUCOM [http:/ /en.YUCOM.org.rs/]). 
men and women. All identified their nationality as Serbian although participants variously described belonging to, or having come from various parts of former Yugoslavia. All participants were fluent in English.

\subsection{Analysis}

A qualitative grounded theory paradigm was employed to analyze the interview data. In qualitative research, the researcher contributes undeniably to the analysis by ascribing meaning to data retrieved from people in particular settings (Creswell 2013, p. 44). This paradigm therefore recognizes that the researcher interprets the data toward building their theory around a socially constructed reality (Corbin and Strauss 1998, p. 12). The initial units of data-nine interviews-were transcribed using a word processor. Then, for each unit, a preliminary three-stage analysis process of line-by-line open-coding was performed. This "open-coding" was conducted to distill the data into meaningful components. Through open coding, "[e]vents, happenings, objects, and actions/interactions that are found to be conceptually similar in nature or related in meaning are grouped under more abstract concepts termed 'categories'" (Strauss and Corbin 1990, p. 102). Codes included for example: access to services, awareness of disability, help-seeking behaviors, language barriers, psychological harm, and violence. Axial coding was then used to identify and reassemble the codes, described as the process "whereby data are put back together in new ways after open coding, by making connections between categories" (Strauss and Corbin 1990, p. 96). Finally, a general inductive analysis was conducted in thematically analyzing these categories in order to identify emergent themes from across the interview data. An inductive approach "primarily uses detailed readings of raw data to derive concepts, themes, or a model through interpretations made from the raw data by an evaluator or researcher" (Thomas 2006, p. 238).

\section{Key Findings}

\subsection{Awareness of Needs of Migrants with Disabilities}

Participants confirmed that settlement services recognize the increasing numbers of migrants presenting with psychiatric and mental health needs, bringing into sharper relief the evolving circumstances and human rights protections required of migrants with disabilities in Serbia.

Several service providers began by acknowledging a decrease in migrants requiring immediate needs such as shelter, food, and medical services. They observed, however, a corresponding increase in migrants seeking social and psychological supports, and opportunities to gain language and employment skills. Awareness of migrants with disabilities was cultivated through the long term relationships formed between service providers and migrants. For example, post-traumatic stress disorder (PTSD) became more evident to psychological service providers among migrants as they settled into government reception centers. Migrants with physical disabilities were also common knowledge among front-line workers, for example migrants who became disabled in debilitating automobile accidents while transiting through the Balkans. Despite this, some of the legal advocacy organizations working at arms-length from accommodation centers did not recognize physical disability as a barrier for migrants because they did not believe they would be able to commence the journey for asylum in the first place.

Praxis, a human rights advocacy organization, suggested that the diversity of migrants with disabilities became evident from working on the ground with migrants. Service providers worked with individuals for example who are deaf, mute, paraplegic, or with cerebral palsy. Meanwhile, awareness of migrants' needs was also inferred from those migrants who expressed their desire to speak directly with a psychologist present at the camps for mental health reasons. However, given the volume of such requests, a lawyer from YUCOM, a Serbian legal aid service provider, relayed the lack of psychosocial services as a "desperate" situation in government reception centers. Migrants frequently presented with depression and trauma, and were sought to speak with anyone willing to listen: 
Whenever we go there [reception centre] someone is like can we talk to you about anything, I can't provide any psychosocial services, but okay let's speak [...] the last time I went there, um when people were actually crying when they saw us, they couldn't believe, that's what I told you, finally someone came here. (Interview participant \#6, 28 August 2017)

Service providers agreed that long-term supports for migrants overall remained critical in Serbia. For example, the UNHCR Press Officer stated that $60 \%$ of migrants have been in Serbia for over 6 months, while Medecins Sans Frontieres discussed the long-term psychological toll on migrants, many of whom have spent several years transiting between refugee camps in Bulgaria, Turkey and other countries in the Balkans.

Service providers such as MSF, Praxis and InfoPark ${ }^{13}$ indicated that the increased length of time spent in Serbia was linked to the deterioration of migrants' mental health through self-harm, depression, and suicidality. InfoPark characterized the situation of migrants in Serbia as increasingly acute because of the EU-Turkey deal media coverage and consequent reduced international funding. The complexity of the issue is compounded by the assumption that the crisis had ended in Serbia and the relative lack of resources for dealing with migrant mental health in Serbia. Migrants left behind in Serbia are consequently making riskier choices. A Field Protection Officer from InfoPark explained:

[...] Per week, we have the same number of arrivals that Greece and Italy have per day. So in that regard it's very, I mean it's far easier ... You can count individual everyone that arrives, but the cases that we take up are quite serious because people have been longer here. The main concern currently of refugees is their mental health ... They have enough accommodations, the asylum procedure is adjusted to this number of people, the transportation, every other, but their mental health is decreasing rapidly and there is a rise in violence and self harm; so we have fewer people but their problems are getting deeper. ${ }^{14}$ (Interview participant \#5, 23 August 2017)

Given the protracted duration of migrants in Serbia, awareness of migrants with disabilities-and the criticality of their needs-has become commonplace among service providers.

\subsection{Invisibility of Disability among Funders}

The monitoring and identification of migrants with disabilities presents a challenge to service providers. A UNHCR Press Officer stated that official statistics on migrants with disabilities do not exist because the UNHCR does not monitor disability among migrants. Praxis described migrants with disabilities as virtually "invisible" to funding agencies and settlement services as well. One issue posited is the lack of accessible services for migrants with disabilities, which key informants suggested deters migrants with disabilities from coming forward.

Key informants provided various examples of how the needs of migrants with disabilities are obscured by intersecting social and structural issues faced in resettlement. They cited challenges facing migrants with disabilities as a result of belonging simultaneously to several marginalized communities, such as LGBT, ethno-cultural, and elderly communities. The invisibility of migrants with disabilities was also underscored by key informants who suggested that the community's needs were compounded by the dynamics of migration through lateral and gender-based violence. For example, migrant women with mental disabilities are additionally vulnerable through their exposure to sexual exploitation. A lawyer from YUCOM working on the ground with migrants discussed her frustration attempting to empower these victims as follows:

13 InfoPark is an organization that works with asylum-seekers often before they are received by government camps. During the interview, migrants knocked on the building's front door and explained they had just arrived after crossing the border the previous night.

14 Following a member check with this participant, she cited the increasing number of incarcerations of migrants with mental health issues. Most recently, InfoPark noted 4-5 such cases in December 2017. 
Additionally those two girls as I've been told are having some mental illness. Then some people said they were forced to do it, others said that they want to because they need money.... I don't know what I could have done ... or the other thing I could do is to report them to the police which would have been the right thing to do from the legal point of view but from the human perspective they would end up in jail, and that's it. So you have that kind of situation, and I tried to find some psychosocial support to go there and do something, nope. As far as I know, no one went. And it's really tough you know, because I couldn't speak to anyone about that. (Interview participant \#6, 28 August 2017)

Migrant women with disabilities being sexually exploited may be rendered invisible by the criminalization of sex work in Serbia.

In addition, stigma compounds the invisibility of migrants with disabilities. The key informant from InfoPark suggested that community-based stigma contributes to the invisibility of people with disabilities during their initial reception. Migrants with disabilities are reluctant to disclose for example mental disability, to each other and service providers.

Key informants such as the Psychosocial Innovation Network (PIN) ${ }^{15}$ and the Belgrade Centre for Human Rights also expressed their discontent with the lack of programs in Serbia dedicated to migrants with disabilities. On-the-ground service providers cited for example the lack of understanding and support for services for migrants with disabilities. The Senior Psychologist from PIN suggested:

I think it is still not recognized particularly by government entities how important it is [...] they think there are other [emphasized] priorities and of course there are a lot of priorities, but some organizations are just not able to do their job properly because the need of their type of support is not recognized, and when it comes to psychosocial support, that is just ignorant. (Interview participant \#10, 1 September 2017)

The paucity of services and funding specific to migrants with disabilities, in the view of key informants, could viably compound the invisibility of migrants with disabilities.

\subsection{Lagging Service Adaptation to Evolving Needs}

Conversations with service providers often began with reference to Serbia's current migrant situation and the existing services available to them. Service providers and the UNHCR attested to the lack of services specific to refugees from marginalized communities. Services that exist are primarily in the domain of first response and basic needs (shelter, food, first aid, etc.). The Red Cross suggested that due to flooding in 2014, Serbian frontline service providers were relatively well-prepared to tackle immediate needs of migrants by providing first aid kits with blankets and parcels of non-perishable food.

Meanwhile, settlement services were relatively less prepared for migrants' long term needs. Two sources of psychosocial support were referenced by key informants: PIN and InfoPark. Legal services were also available through Praxis and YUCOM. Social supports funded by the UNHCR in partnership with local service providers discussed by the UNHCR Press Officer included integration activities for migrants such as cultural site visits, arts and language programming, and more recently formalized schooling for migrant children. However, services, particularly at government reception centers-of which there are 18 , are predominantly medical-oriented. When asked about the longterm services for migrants given their protracted stays, the UNHCR focused on medical assistance, for example:

As the situation changed, the government opened more centres, the services changed, the types of services and the character changed, many of the centres now, almost all of the centres have a medical unit within them, in order to respond

15 The Psychosocial Innovation Network (PIN) is the only organization in Serbia that specializes in providing psychological services to vulnerable populations. Its programme for migrants receives funding from the UNHCR. 
to the emergency cases, right [...] so when services are provided, when doctors the medical centre have a case and if the doctors cannot, the situation is more grave, they refer them to the local health care centre and some specialized care if required ... so refugees and migrants and asylum seekers, those in the centres have access to full health care. (Interview participant \#9, 31 August 2017)

In contrast, PIN cited the inadequacy of supports for migrants with disabilities in the healthcare system, and the need for job creation among those migrants who are consequently forced to stay in Serbia. In describing the condition of several migrants from Nigeria who were physically disabled by a car accident, PIN's key informant recounted:

Again, our country doesn't really have a solution for them [the Nigerian migrants], they don't want to stay here but they are somehow forced to stay here, legally, they can't resettle at this moment, and the health system doesn't have appropriate support at this moment. [...] trying to help them move forward if they are in the end in a situation if they have to stay here, provide them with a job as well [...] to work online, something like that. ${ }^{16}$ (Interview participant \#10, 1 September 2017)

Several service providers suggested that funding for social needs indeed lags behind the current circumstances of migrants in Serbia. Projects related to social settlement such as a photography project funded by United States Agency for International Development (USAID) and women's workshops at InfoPark were cited by key informants, but disability is not a sub-group explicitly targeted nor funded by any organization in Serbia.

Finally, service providers framed the inattention to disability against the social backdrop of disability rights in Serbia, suggesting that entrenching, or "mainstreaming" the rights of people with disabilities is first necessary to protect migrants with disabilities. Overall, the neglect of current realities of migrants, particularly in light of increased incidences of disability and mental health issues, depicts the lagging response of services to emerging needs and human rights violations of migrants with disabilities.

\section{Discussion}

\subsection{Descending from the Attic: Bridging the Gap in Funding and Services for Migrants} with Disabilities

The key informants illuminate the ongoing crisis for migrants in Serbia and in particular those with disabilities. This discussion locates these findings in the shortcoming of international refugee funding models and proposes changes to the current system to protect the human rights of migrants with disabilities.

The key informants bring to the foreground the disparity between legal standards for accommodating migrants with disabilities and the on-the-ground reality. Settlement practice for migrants with disabilities neither meets the standards set out by the ECtHR nor the provisions required of Serbia to join the EU, but largely by no fault of the service providers themselves. Nevertheless, this research exposes the presence of migrants with disabilities in Serbia, and the need to address this community's needs in order to align with both the SDGs and EU accession mandates. Meeting these requirements, and more broadly upholding human rights globally, necessitates targeted funding and programs by the UNHCR and international donors. Funding however is a concern repeatedly echoed in the current migrant crisis (Crock et al. 2017, pp. 231, 240, 268). Although critical, funding is only one means of addressing the rights of migrants with disabilities, which is first discussed prior to the alternatives.

16 In a subsequent 'member check' with key informants to ensure the accuracy of quotes used, PIN clarified that disability resulting from injury occurred with migrants from other countries as well, this was merely one example. 


\subsubsection{Economic Integration of Migrants with Disabilities and "Hot-Potato" Funding}

The key informants reveal the lack of adapted settlement services and funding for migrants with disabilities, despite the continued urgency of their needs. The call for a revamped approach to global refugee settlement, in particular for those with disabilities, is not new. Betts and Collier criticize the international funding regimes for refugee resettlement, citing that a disproportionately low amount of money is spent on migrants in developing countries: USD seventy-five billion is spent annually on the $10 \%$ of refugees who reach a developed country, whereas USD 5 billion is spent on the remaining $90 \%$ (Betts and Collier 2017).

The disparity of funding between the global south and developing countries is questionable from a human rights perspective. Whereas refugee settlement models in Africa and Central America swiftly integrate refugees into the local economy, European models of aid focus primarily on basic needs. As depicted by the key informants, international organizations such as Red Cross provide basic needs, which while necessary, cannot in themselves support the emerging long-term settlement of migrants in Serbia. Notably, refugee camps or reception centers, which house $90 \%$ of migrants in Serbia ${ }^{17}$, are not capable of promoting the rights of migrants with disabilities. The example of Nigerian migrants who were physically disabled during their transit demonstrate that long-term solutions ought to sustain migrants' capacities to integrate into society rather than remain recipients of medical aid and basic necessities.

Betts and Collier (2017) argue further that refugee camps are ineffective and outdated, drawing on what they cite is a misguided "global humanitarian industry" committed to distributing food, tents, and blankets whereas the ultimate outcomes-settlement and even citizenship—are reserved for few. Hathaway (1990, p. 161) argues that the UNHCR's mandate is subordinated by the "goodwill" of developed countries because of their reliance on the funding of these wealthier States. In the context of disability rights, Meyers identifies another unintentional consequence of external funding of organizations promoting disability rights (Meyers 2016). Civil society organizations and NGOs—such as those primarily responsible for delivering settlement services to migrants in Serbia-effectively have their mandate co-opted by external funders, a phenomenon Meyers (2016) calls "NGO-ization". Capacity-building programs for migrants with disabilities are thereby hindered by funding that emphasizes formalization and professionalization processes to the detriment of on-the-ground realities.

Current international funding, which shifts the burden of economic integration of migrants disproportionately to those countries that are under-developed, amounts to an international version of the children's game 'hot-potato'. Consider the UNHCR's estimate of 65.6 million displaced people globally 2016, which has only swelled in the last year reported to 79.5 million in 2019 (UNHCR 2020). Yet only 1.64 million asylum applications were made in OECD (Organisation for Economic Co-operation and Development) countries in 2016, three quarters of which were submitted in EU States. Meanwhile, The OECD (2017) International Migration Outlook situates the global "humanitarian crisis" in the backdrop of increasing GDP and decreasing unemployment in OECD countries. Ostensibly, EU Member States prefer funding foreign projects for migrants, deflecting the domestic integration of migrants to already under-resourced countries. The aforementioned EU-Turkey deal and international donations to developing countries reflect a continued habit of passing the buck, or 'hot potato', of migrant integration to countries less capacitated to actually do so.

On the receiving, or losing end of hot potato are also migrants with disabilities. As the key informants illustrated, the lack of funding in addition to social marginalization and lack of mobility compounds the status of migrants with disabilities. This lack of funding

17 "As a result of the arrival of large numbers of people into southern Europe that accelerated two years ago this month, there are 7600 refugees in Serbia, according to the UN refugee agency (UNHCR). Most live in 18 state-run asylum centres that provide basic necessities." See Border Monitoring "Blocked in the Balkans: The Refugees that Europe Won't Allow In" (8 August 2017). Available online: http://serbia.bordermonitoring. eu/2017/08/08/blocked-in-the-balkans-the-refugees-that-europe-wont-allow-in/ (accessed on 14 January 2021). 
renders them invisible to service providers. Simultaneously, migrants with disabilities are already disadvantaged in the refugee claimant process facing an added burden of justifying the persecution they face. Yet in Serbia, and across many European countries, the focus on migrants with disabilities lags behind the law, effectively limiting the integration of migrants most on the margins of society.

Socio-economic integration of migrants with disabilities exposes a tension explored by Harnacke relative to disability rights. Harnacke juxtaposes the normative assumptions undergirding the CRPD—for example that persons with disabilities ought to be empowered to participate in society - with the reality that States hesitate to enforce these rights because of the costs associated with accommodations (Harnacke 2013, p. 769). Disability rights activists argue vehemently against these economic arguments and contractarian theories of justice. Rather, Nussbaun and Harnacke contend that persons with disabilities ought to be capacitated in order to be capable of contributing, regardless of their nationality or circumstance (Harnacke 2013). Equally then, migrants with disabilities ought to not be viewed in purely utilitarian terms, that is, as mere economic burdens. The full realization of their human rights necessitates adapting current tools and services toward enabling migrants with disabilities to fully achieve their capabilities in countries of asylum.

The findings nuance the criticism of funding disparities in under-developed countries advanced by Betts and Collier (2017). Lack of funding sheds light on the disproportionate impact of inadequate settlement support for those migrants who have disabilities. In the experience of one key informant for example, migrant women with disabilities are involuntarily exposed to sex work. The social stigma and perceived economic burden of integration of migrants with disabilities thereby continues to marginalize this community in the provision of international services and international funding dedicated to their resettlement, especially in under-developed countries.

Similarly, screening mechanisms and inventories exist for monitoring migrants' mental health, however their implementation by the UNHCR in Serbia was not elicited in the interviews. Crock et al. (2017) suggest several such recent inventories. These include the UNHCR's Resettlement Assessment Tool, the Sendai Framework for Disaster Risk Reduction (adopted by UN member states in 2015), and the Charter on the Inclusion of Persons with Disabilities in Humanitarian Action endorsed by the UNHCR and international development and disability advocacy organizations at a 2016 World Humanitarian Summit. The Committee on the Rights of Persons with Disabilities report on Serbia furthermore suggests the implementation of the Sendai Framework in the context of humanitarian emergencies. ${ }^{18}$

\subsubsection{Critical Disability Theory and Humanitarian Silos}

The aforementioned focus on the medical needs and economic burden of migrants with disabilities (as opposed to their potential for integration) reveals a medical or charitable understanding of disability. These approaches view disability as the product of an individual's biological deficits, or 'pathology', whereas the social model attributes these deficits to their environment (Pothier and Devlin 2006, p. 50). The current funding approach to migrants with disabilities as subjects requiring medical services rather than services that instead empower them or challenge social barriers evokes the medical model of disability. This approach reveals the issue of silos in funding for migrant resettlement.

Betts and Collier (2017) refer to humanitarian silos as the one-dimensional approach generally taken to refugee settlement funding. Humanitarian silos are premised on an outdated model of migrant resettlement concerned solely with emergency services. The focus on the external provision of food, clothing, and shelter, they argue, while essential in the immediate aftermath of conflict, erodes the long-term human dignity and autonomy of migrants.

18 Notably, the Committee expressed concern about Serbia's lack of a general strategy "to protect and assist persons with disabilities in situations of risk and humanitarian emergencies" and encouraged a "fully accessible and comprehensive emergency strategy". UNCRPD, Committee on the Rights of Persons with Disabilities Concluding Observations on the Initial Report of Serbia, UN Doc GE.16-08243 (UNCRPD 2016) at para. 19-20. 
The notion of 'humanitarian silos' is replicated in the plight of migrants with disabilities both in Serbia and abroad. Key informants for instance referenced the lag in funding adapted to current circumstances of long-term migrants in the country. Existing programs target broad demographics in Serbia, such as women's groups, educational programs for youth, and adult language programs. Community-based needs however, particularly those of migrants with disabilities, have in their experiences largely been neglected. This lack of targeted funding and policies undermines the visibility of my migrants with disabilities, reinforcing international 'humanitarian silos' in migrant resettlement funding.

Human rights scholar Brooke Ackerly (2011) also argues that human rights cannot be viewed in "issue silos". Using the CRPD as an example, Ackerly makes explicit that various forces political, social, and economic factors impact the enjoyment of human rights. Human rights are interrelated and therefore require change from not only State actors, but funders to promote all rights within the overlapping social spheres in society. With respect to migrants with disabilities, the impetus for upholding their rights-in part being Serbia's EU accession-is in tension with the theory of change proposed by Ackerly (2011, p. 226). The enjoyment of rights of peoples with disabilities ought to encompass social and economic change, not merely political change to effect the sustained enjoyment of human rights in Serbia. A community-based model of funding and settlement adapted to migrants' long-term needs would conceivably not only consider the humanitarian, or emergency aspects of settlement, but plan for long-term settlement and accommodations of migrants with disabilities.

\subsubsection{Moving Forward and Recommendations}

As Europe attempts to move beyond the migrant crisis, several lessons are to be had. First, an intersectional approach in funding is urged. Migrants with disabilities are at the intersections of multiple forms of human rights violations, and their rights must be viewed in light of these dimensions. Given the social framework of disability espoused by the CRPD and the capabilities approach endorsed by disability rights advocates, funding ought to address the intersecting rights abuses facing migrants with disabilities. In the 2016 European Parliament report on the implementation of the CRPD, several committees specifically acknowledged intersectional discrimination facing migrants with disabilities (EC 2016a, p. 62).

The findings shed light on these challenges-gender intersects with disability for example through gender-based violence and sexual exploitation. Sex trafficking of women and children for example often intersects with disabilities whether intellectual, physical, or learning disabilities (Deshpande and Nour 2013). Sex trafficking can additionally lead to the development of mental disabilities such as PTSD, addiction, and depression (Greenbaum and Crawford-Jakubiak 2015).

Dismantling of silos in funding and the increased transparency and visibility of programs are proposed to address the aforementioned shortcomings. However mental health and stigma need to be mainstreamed in migrant discourse in Serbia and abroad, while adapted funding models are necessary to protect the most vulnerable among the migrant communities. Crock et al. (2017) acknowledge that although refugees and migrants are often staying for longer periods in developing countries, minor adjustments to accommodations can have a large impact in terms of reducing discrimination and increasing the quality of life and human rights of migrant with disabilities. "Small accommodations can make a big difference. Improved programme design can address both explicit and indirect discrimination and significantly improve quality of life" (Crock et al. 2017, p. 276).

In addition, under Article 32 the CRPD calls for the cooperation of States, and for the accessibility and inclusivity of international development programs for people with disabilities. The implementation of inventories and psychosocial assessments such as the Sendai Framework and collocated services, monitoring, and record-keeping with other organizations even across borders could facilitate a wraparound model of service for all migrants. International cooperation could also cultivate knowledge-sharing of issues and 
gaps between services, enabling settlement services to better prepare and more efficiently allocate resources in addressing the migrant crisis.

Moreover, improved cooperation between States could enhance monitoring of migrants with disabilities. As illustrated by the key informants, organizations currently rely on anecdotal evidence of migrants with disabilities' needs. The visibility of this community's needs, and lack of data collection thereof, remains a critical barrier to the accessibility of appropriate services. A joint statement by the Committee on the Protection of the Rights of All Migrant Workers and Members of their Families (CMW) and the Committee on the Rights of Persons with Disabilities in 2017 links this lack of data to States' inability to "fulfil their legal duty to ensure effective protection and safety in situations of risk and to provide services that meet their specific requirements." (Office of the High Commissioner 2017)

The European Union Agency for Fundamental Rights (2017) also cites a lack of both systematic data and formal procedures to identify migrants with disabilities, relying instead on anecdotal evidence. These barriers to effective monitoring adversely impact the provision of targeted support and assistance. Crock et al. $(2017$, p. 5) also note the lack of reliable data suggesting that little is known about the accommodations and any adjustment made in settlement procedures for migrants with disabilities. Testament to this, the current study also faces limits from its methodology. Interviews were conducted with members working internally for various service-side or advocacy organizations working in Serbia. Inferences made based on this case study ought to bear in mind the cross-section in time at which these data were obtained and the limited number and type of participants involved.

In addition to being under-reported, certain disabilities are overlooked initially and manifest instead in the long-term such as PTSD (Crock et al. 2017, p. 71). International cooperation in record-keeping and communication with other services is therefore critical to the long-term support for migrants (and eventually refugees whose claims are accepted) across borders.

\section{Conclusions}

The resettlement of migrants with disabilities exposes not only gaps between law and practice, but also the necessity for international cooperation in monitoring and advocating for the human rights of migrants with disabilities. Serbia's accommodations of this community, notwithstanding de jure protections, fails-although hardly by any fault of its own - to translate from theory into practice. This lack of international comity leaves some of the most vulnerable migrants perpetually in the proverbial attic.

Migrants with disabilities face continued discrimination and structural violence prior to, and during, resettlement. The inattention to migrants with disabilities globally and inadequate supports for these migrants in Serbia warrants specific funding and service delivery to mitigate the heightened risks facing these migrants both in transit and in refugee camps. Finally, the adjustments to accommodation and monitoring can inform multi-lateral strategies for countries working with migrants with disabilities internationally, a proposition which is increasingly important as migrants reside longer in de facto destination countries, the globe over.

Funding: This research received no external funding.

Institutional Review Board Statement: The study was conducted according to the guidelines of the Declaration of Helsinki, and approved by Mental Disability Rights Initiative Serbia (MDRI-S).

Informed Consent Statement: Informed consent was obtained from all subjects involved in the study.

Data Availability Statement: The data presented in this study are available on request from the corresponding author. The data are not publicly available due to participant confidentiality.

Conflicts of Interest: The author declares no conflict of interest. 


\section{References}

Ackerly, Brooke. 2011. Human Rights Enjoyment in Theory and Activism. Human Rights Review 12: 2. [CrossRef]

Aljazeera. 2016. News Release. Hungary Leaves Refugees Stuck on Serbian Border. July 7. Available online: http: //www.aljazeera.com/news/2016/07/hungary-border-controls-leave-refugees-stuck-border-160707131922016.html (accessed on 7 February 2021).

Basser, Lee Ann. 2001. Human Dignity. In Critical Perspectives on Human Rights and Disability Law. Edited by Marcia H. Rioux, Lee Ann Basser and Melinda Jones. Boston: Martinus Nijhoff Publishers, pp. 17-18.

Betts, Alexander, and Paul Collier. 2017. Chapter 5 Rethinking Havens: Reaching Everyone. In Refuge: Transforming a Broken Refugee System. London: Penguin UK, p. 288.

Beznec, Barbara, Marc Speer, and Marta Stojić Mitrovićat. 2016. The turn from humanitarianism to securitization in discourse and migration policy. In Governing the Balkan Route: Macedonia, Serbia and the European Border Regime. Edited by Barbara Beznec, Marc Speer and Marta Stojić Mitrovićat. Belgrade: Rosa Luxemburg Stiftung Southeast Europe.

Birt, Linda, Suzanne Scott, Debbie Cavers, Christine Campbell, and Fiona Walter. 2016. Member Checking: A Tool to Enhance Trustworthiness or Merely a Nod to Validation? Qualitative Health Research 26: 1802-11. [CrossRef] [PubMed]

Charter of Fundamental Rights of the European Union. 2000. OJ C 364, Art 21 (Entered into Force 1 December 2009 ). December 18. Available online: https:/ / www.europarl.europa.eu/charter/pdf/text_en.pdf (accessed on 7 February 2021).

Committee of Ministers of the Council of Europe. 2006. Continuation by the Republic of Serbia of membership of the State Union of Serbia and Montenegro in the Council of Europe: Declaration by the Committee of Ministers of the Council of Europe. Paper presented at 967th Meeting (Item 2.3a); Available online: https://rm.coe.int/168071dd21 (accessed on 7 February 2021).

Committee of Ministers of the Council of Europe. 2019. Guidelines on Human Rights Protection in the Context of Accelerated Asylum Procedures. Paper presented at 2009 1062nd Meeting of the Ministers' Deputies, July 1; Available online: https:/ /rm.coe.int/ CoERMPublicCommonSearchServices / DisplayDCTMContent?documentId=09000016806aff8b (accessed on 7 February 2021).

Corbin, Juliet, and Anselm Strauss. 1998. Basics of Qualitative Research: Tehcniques and Procedures for Developing Grounded Theory. Thousand Oaks: Sage Publications.

Council of Europe. 2011. Council of Europe Standards and Guidelines in the Field of Human Rights Protection of Irregular Migrants. Committee of Ministers, art II(a)(3). Available online: https:/ / fra.europa.eu/fraWebsite/frc2011/docs/CoE-standards-hr-protection-irregmigrants.pdf (accessed on 7 February 2021).

Creswell, John W. 2013. Qualitative Inquiry and Research Design: Choosing among Five Approaches. Newbury Park: Sage Publications, p. 448.

Crock, Mary E., Laura Smith-Khan, Ron McCallum, and Ben Saul. 2017. The Legal Protection of Refugees with Disabilities: Forgotten and Invisible? Northampton: Edward Elgar Publishing, p. 336.

Deshpande, Neha A., and Nawal M. Nour. 2013. Sex trafficking of women and girls. Review in Obstetrics E Gynecology 6: 22.

EC. 2011. Directive 2011/95/EU of the European Parliament and of the Council of 13 December 2011 on standards for the qualification of third-country nationals or stateless persons as beneficiaries of international protection, for a uniform status for refugees or for persons eligible for subsidiary protection, and for the content of the protection granted, OJ, L 337. December 13.

EC. 2016a. Report on the implementation of the UN Convention on the Rights of Persons with Disabilities, with special regard to the Concluding Observations of the UN CRPD Committee, 9 June, [2016] A8-0203.

EC. 2016b. Communication from the Commission to the European Parliament, the Council, the European Economic and Social Committee and the Committee of the Regions: 2016 Communication on EU Enlargement Policy, OJ, C 715/F1. Available online: https:/ / eur-lex.europa.eu/legal-content/en/TXT/?uri=CELEX\%3A52016DC0715 (accessed on 7 February 2021).

EC. 2016c. Communication from the Commission to the European Parliament, the Council, the European Economic and Social Committee and the Committee of the Regions: Proposal for a New European Consensus on Development Our World, Our Dignity, Our Future, [2016] COM, 0740. Available online: https:/ / eur-lex.europa.eu/legal-content/EN/TXT/?uri=CELEX\%3A5 2016DC0740 (accessed on 7 February 2021).

EC. 2016d. Communication from the Commission to the European Parliament, the Council, the European Economic and Social Committee and the Committee of the Regions: Next Steps for a Sustainable European Future, [2016] COM, 0739. Available online: https:/ / eur-lex.europa.eu/legal-content/EN/TXT/PDF/?uri=CELEX:52016DC0739\&from=EN (accessed on 7 February 2021).

EC. 2016e. Sustainable Development in the European Union: A Statistical Glance from the Viewpoint of the UN Sustainable Development Goals (Luxembourg: Publications Office of the European Union, 2016). Available online: https: / / ec.europa.eu/ eurostat/web / products-statistical-books /- /KS-02-16-996 (accessed on 7 February 2021).

EC. 2017. Implementation of the European Disability Strategy: European Parliament Resolution of 30 November 2017 on Implemenation of the European Disability Strategy, 30 November 2017, Texts Adopted [2017] P8_TA-PROV(2017)0474. November 30.

ECHR. 1950. European Convention for the Protection of Human Rights and Fundamental Freedoms, 4 November 1950. 213 UNTS 221, art 14 (entered into force 3 September 1953, accession by Serbia 3 March 2004) [ECHR]. November 4.

European Court of Human Rights [ECtHR]. 2009. European Court of Human Rights [ECtHR], Strasbourg. Slawomier Musial v. Poland, January 20.

European Court of Human Rights [ECtHR]. 2011. European Court of Human Rights [ECtHR], Strasbourg. M.S.S. v. Belgium and Greece, January 21. 
European Union Agency for Fundamental Rights. 2017. Thematic Focus: Migrants with Disabilities. European Union Agency for Fundamental Rights. Available online: https:/ / fra.europa.eu/sites/default/files/fra_uploads/fra-august-2016-monthlymigration-disability-focus_en.pdf (accessed on 7 February 2021).

Gagnon, Yves-Chantal. 2010. The Case Study as Research Method: A Practical Handbook. Québec: Presses de l'Université du Québec.

Gogou, Kondylia. 2017. The EU-Turkey deal: Europe's year of shame. Amnesty International. March 20. Available online: https: / / www.amnesty.org/en/latest/news/2017/03/the-eu-turkey-deal-europes-year-of-shame/ (accessed on 7 February 2021).

Greenbaum, Jordan, and James E. Crawford-Jakubiak. 2015. Child sex trafficking and commercial sexual exploitation: Health care needs of victims. Pediatrics 135: 566. [CrossRef] [PubMed]

Handicap International. 2014. Hidden Victims: Radical Change Needed for Older, Disabled and Injured Syrian Refugees. Handicap International. April 9. Available online: https://www.helpage.org/newsroom/press-room/press-releases/hidden-victimsradical-change-needed-for-older-disabled-and-injured-syrian-refugees/ (accessed on 7 February 2021).

Harnacke, Caroline. 2013. Disability and Capability: Exploring the Usefulness of Martha Nussbaum's Capabilities Approach for the UN Disability Rights Convention. The Journal of Law, Medicine E Ethics 41: 768.

Harpur. 2012. Embracing the New Disability Rights Paradigm: The Importance of the Convention on the Rights of Persons with Disabilities. Disability \& Society 27: 1-14.

Hathaway, James C. 1990. A Reconsideration of the Underlying Premise of Refugee Law. Harvard International Law Journal 31: 161.

Hathaway, James C. 1991. Reconceiving Refugee Law as Human Rights Protection. Journal of Refugee Studies 4: 113-131. [CrossRef]

Human Rights Watch. 2017. Serbia/Kosovo: Events of 2016. Human Rights Watch. Available online: https://www.hrw.org/worldreport/2017/country-chapters/serbia/kosovo (accessed on 7 February 2021).

Ktistakis, Yannis. 2016. Protecting Migrants under the European Convention on Human Rights and the European Social Charter, 2nd ed. Strasbourg: Council of Europe Publishing.

Mackelprang, Romel W., and Richard O. Salsgiver. 2016. Contemporary International Approaches to Disability in Disability: A Diversity Model Approach in Human Service Practice, 3rd ed. New York: Oxford University Press.

Mental Disability Rights Initiative-Serbia [MDRI-S]. 2011. Mental Disability Rights Initiative of Serbia (MDRI-S): Partial Report on Implementation of Recommendations as Accepted by Serbia at the Human Rights Council, (Paper delivered to Universal Periodic Review (UPR) 29 August 2011). Available online: https://www.upr-info.org/followup/assessments/session15/serbia/MDRIserbia.pdf (accessed on 7 February 2021).

Meyers, Stephen. 2016. NGO-Ization and Human Rights Law: The CRPD's Civil Society Mandate. Laws 5: 21. [CrossRef]

Morris, Eleanor G., and Manonh L. Souhmahoro. 2017. Free Movement for All? Restrictive Practices, Human Rights Violations and European Governance. In The Challenges of European Governance in the Age of Economic Stagnation, Immigration, and Refugees. Edited by Henry F. Carey. Lanham: Lexington Books.

OECD. 2017. International Migration Outlook 2017. Paris: OECD Publishing.

Office of the High Commissioner. 2017. Addressing Disabilities in Large-Scale Movements of Refugees and Migrants Joint Statement by the Committee on the Protection of the Rights of All Migrant Workers and Members of Their Families (CMW), and the Committee on the Rights of Persons with Disabilities (CRPD). United Nations Human Rights. April 12. Available online: http:/ / www.ohchr.org/Documents/HRBodies/CMW /JointStatementCMW-CRPDFINAL.pdf (accessed on 7 February 2021).

Peers, Steve, Elspeth Guild, Diego Acosta Arcarazo, Kees Groenendijk, Violeta Moreno-Lax, and Jonathan Tomkineds. 2015. EU Immigration and Asylum Law Volume 3: EU Asylum Law, 2nd ed. Boston: Hotei Publishing.

Peterson, Vandana. 2014. Understanding Disability under the Convention on the Rights of Persons with Disabilities and Its Impact on International Refugee and Asylum Law. Georgia Jounral of International and Comparative Law 42: 687-742.

Pothier, Dianne, and Richard Devlin, eds. 2006. Critical Disability Theory: Essays in Philosophy, Politics, Policy, and Law. Vancouver: UBC Press.

Speer, Marc. 2017. Die Geschichte des Formalisierten Korridors: Erosion und Restrukturierung des Europäischen Grenzregimes auf dem Balkan Bordermontoring. München: Bordermonitoring.eu.

Squire, Nick. 2017. A Year on from EU-Turkey Deal, Refugees and Migrants in Limbo Commit Suicide and Suffer from Trauma. The Telegraph. March 14. Available online: http:/ / www.telegraph.co.uk/news/2017/03/14/year-eu-turkey-deal-refugees-migrantslimbo-commit-suicide-suffer/ (accessed on 7 February 2021).

Strauss, Anselm, and Juliet Corbin. 1990. Basics of Qualitative Research. Newbury Park: Sage Publications.

Thomas, David R. 2006. A general inductive approach for analyzing qualitative evaluation data. American Journal of Evaluation 27: 237-46. [CrossRef]

Treaty on the Functioning of the European Union. 2007. 13 December. OJ C 326 at Art. 67. (entered into force 26 October 2012) [TFEU]. Available online: https:/ / eur-lex.europa.eu/LexUriServ/LexUriServ.do?uri=OJ:C:2012:326:FULL:EN:PDF (accessed on 7 February 2021).

UN. 1966. International Covenant on Civil and Political Rights, UN General Assembly, 19 December, 999 UNTS 171 arts 2.1 and 26 (entered into force 23 March 1976, accession by Serbia 12 March 2001) [ICCPR].

United Nations [UN]. 2008. Convention for the Rights of Peoples with Disabilities, 13 December 2006, UNTS 2515 (entered into force 3 May 2008, ratification by Serbia 31 July 2009) [CRPD].

UNCRPD. 2016. UNCRPD, Committee on the Rights of Persons with Disabilities Concluding Observations on the Initial Report of Serbia, UN Doc GE.16-08243. 
UNDP. 2017. UNDP, Sustainable Development Goal Analysis Mission for Western Balkans One-Day Mission to the Republic of Serbia: Understanding Linkages and Opportunities for Sustainable Development Linked to SDGs and EU Accession, 21 June 2017 [Meeting] UN House Belgrade, Republic of Serbia.

UNHCR. 2017a. Global Trends: Forced Displacement in 2016. Geneva: UNHCR.

UNHCR. 2017b. UNHCR Serbia Update 6-8 March 2017. Available online: https://data2.unhcr.org/fr/documents/download/54240 (accessed on 7 February 2021).

UNHCR. 2017c. Snapshot Serbia. Available online: https:/ / data2.unhcr.org/en/documents/download/60331 (accessed on 7 February 2021).

UNHCR. 2020. Figures at a Glance. Available online: https: / / www.unhcr.org/figures-at-a-glance.html (accessed on 7 February 2021).

Voynov, Georgi, Hana Franková, Anikó Bakonyi, Marta Górczyńska, and Miha Nabergoj. 2017. Pushed Back at the Door: Denial of Access to Asylum in Eastern EU Member States. Budapest: Hungarian Helsinki Committee.

Warren, Carol AB. 2002. Qualitative Interviewing. In Handbook of Interview Research: Context and Method. Edited by Jaber F. Gubrium and James A. Holstein. Thousand Oaks: Sage Publications. 